\title{
Crystal Growth and Structure of a New $\mathrm{PbHNSO}_{3}$ Crystal
}

\author{
Takanori Fukami ${ }^{1}$, Mitsuhiro Seino ${ }^{1}$, Keiko Nakasone ${ }^{1} \&$ Shuta Tahara ${ }^{1}$ \\ ${ }^{1}$ Department of Physics and Earth Sciences, Faculty of Science, University of the Ryukyus, Japan \\ Correspondence: Takanori Fukami, Department of Physics and Earth Sciences, Faculty of Science, University of \\ the Ryukyus, Okinawa 903-0213, Japan. Tel: 81-098-895-8509. E-mail: fukami@sci.u-ryukyu.ac.jp
}

Received: October 26, 2012 Accepted: December 6, 2012 Online Published: January 9, 2013

doi:10.5539/ijc.v5n1p1

URL: http://dx.doi.org/10.5539/ijc.v5n1p1

\begin{abstract}
A new type of $\mathrm{PbHNSO}_{3}$ crystal has been grown by a gel method using agar-agar gel. TG-DTA and X-ray diffraction measurements have been performed on single crystal samples of $\mathrm{PbHNSO}_{3}$. It is found that the thermal decomposition of the compound starts at about $960 \mathrm{~K}$. The space group (orthorhombic Pnma) and structural parameters are determined at room temperature with unit cell dimensions: $a=8.4690(6), b=5.3934(4)$ and $c=6.9530(4) \AA$. The crystal structure is found to consist of $\mathrm{NSO}_{3}$ pseudo-tetrahedra, $\mathrm{PbO}_{9} \mathrm{~N}_{3}$ polyhedra, and $\mathrm{NSO}_{3}-\mathrm{Pb}-\mathrm{NSO}_{3}$ frameworks. The dark brown color of the crystal is suggested to be caused by the absorption of blue wavelengths of light which is due to the excitation of excess electrons in potential wells produced by the $\mathrm{NSO}_{3}-\mathrm{Pb}-\mathrm{NSO}_{3}$ framework.
\end{abstract}

Keywords: crystal growth, gel method, crystal structure, $\mathrm{PbHNSO}_{3}$, TG-DTA, X-ray diffraction

\section{Introduction}

It is well known that crystals of an $\mathrm{ANH}_{2} \mathrm{SO}_{3}$-type consist of a monovalent cation $\left(\mathrm{A}^{+}=\mathrm{Li}^{+}, \mathrm{Na}^{+}, \mathrm{K}^{+}, \mathrm{Rb}^{+}, \mathrm{Cs}^{+}\right.$, $\mathrm{Ag}^{+}, \mathrm{NH}_{4}{ }^{+}, \mathrm{C}\left(\mathrm{NH}_{2}\right)_{3}{ }^{+}$or $\left.\left(\mathrm{CH}_{3}\right)_{3} \mathrm{NCH}_{2} \mathrm{COOH}^{+}\right)$and a sulfamate $\left[\mathrm{NH}_{2} \mathrm{SO}_{3}\right]^{-}$anion (Belaj et al., 1987; Cox et al., 1967; H. Haussühl \& S. Haussühl, 1995; Manickkavachagam \& Rajaram, 1984; Wadhawan \& Padmanabhan, 1972). The crystal systems, space groups, lattice parameters, and elastic constants of the compounds at room temperature have been listed in the paper as reported by H. Haussühl and S. Haussühl (1995). It is confirmed from these data that three crystals containing larger cations, such as $\mathrm{A}^{+}=\mathrm{Cs}^{+}, \mathrm{C}\left(\mathrm{NH}_{2}\right)_{3}{ }^{+}$or $\left(\mathrm{CH}_{3}\right)_{3} \mathrm{NCH}_{2} \mathrm{COOH}^{+}$, are of monoclinic system, and other crystals are of orthorhombic system. The $\mathrm{KNH}_{2} \mathrm{SO}_{3}$ and $\mathrm{NaNH}_{2} \mathrm{SO}_{3}$ crystals undergo phase transitions at $437.9 \mathrm{~K}$ with a transition enthalpy $\Delta H$ of $4.9 \mathrm{~kJ} / \mathrm{mol}$ and at $456.0 \mathrm{~K}$ with $\Delta H$ of 1.9 $\mathrm{kJ} / \mathrm{mol}$, respectively (Budurov et al., 1997). Recently, it has been reported that the $\mathrm{KNH}_{2} \mathrm{SO}_{3}$ crystal also undergoes another phase transition at $350 \mathrm{~K}$ and becomes an ionic conductor at high temperature, and the $\mathrm{CsNH}_{2} \mathrm{SO}_{3}$ crystal has a structural phase transition from monoclinic $P 2_{1} / c$ to orthorhombic Pnma at $330 \mathrm{~K}$ (Varughese et al., 2010; Kumar et al., 2011; Fukami et al., 2011). The sulfamic acid and its derivatives are interested in industrial applications, and are widely used in a variety of applications such as a fireproofing agent, an anticorrosive agent, a cross-linking agent for polymers, and a cleaning agent for air, etc (Benson \& Spillane, 1980). The $\mathrm{NH}_{4} \mathrm{NH}_{2} \mathrm{SO}_{3}$ and $\mathrm{C}\left(\mathrm{NH}_{2}\right)_{3} \mathrm{NH}_{2} \mathrm{SO}_{3}$ compounds of the $\mathrm{ANH}_{2} \mathrm{SO}_{3}$-type have good abilities as fire retardant (Benson \& Spillane, 1980).

The crystals of an $\mathrm{A}\left(\mathrm{NH}_{2} \mathrm{SO}_{3}\right)_{2}$-type consist of a divalent cation $\left(\mathrm{A}^{2+}=\mathrm{Ca}^{2+}, \mathrm{Mn}^{2+}\right.$ or $\left.\mathrm{Ni}^{2+}\right)$ and the sulfamate $\left[\mathrm{NH}_{2} \mathrm{SO}_{3}\right]^{-}$anion (Angerer et al., 1999). The crystal structure of $\mathrm{Ca}\left(\mathrm{NH}_{2} \mathrm{SO}_{3}\right)_{2} \cdot 4 \mathrm{H}_{2} \mathrm{O}$ is monoclinic with space group $C 2 / c$, and is built up of $\mathrm{CaO}_{8}$ polyhedra and $\left[\mathrm{NH}_{2} \mathrm{SO}_{3}\right]^{-}$anions. Four $\mathrm{O}$ atoms of the polyhedron are shared with four $\left[\mathrm{NH}_{2} \mathrm{SO}_{3}\right]^{-}$anions around the $\mathrm{Ca}^{2+}$ cation. Similarly, the crystal structures of $\mathrm{Mn}\left(\mathrm{NH}_{2} \mathrm{SO}_{3}\right)_{2} \cdot 4 \mathrm{H}_{2} \mathrm{O}$ and $\mathrm{Ni}\left(\mathrm{NH}_{2} \mathrm{SO}_{3}\right)_{2} \cdot 4 \mathrm{H}_{2} \mathrm{O}$ are monoclinic with space group $P 2_{1} / c$ and triclinic with space group $P \overline{1}$, and are built up of $\mathrm{MnO}_{6}$ and $\mathrm{NiO}_{4} \mathrm{~N}_{2}$ octahedra, respectively. Two atoms $(\mathrm{O}$ or $\mathrm{N})$ of the octahedra in the two compounds are also shared with two $\left[\mathrm{NH}_{2} \mathrm{SO}_{3}\right]^{-}$anions around the cations. Moreover, powder and single crystals of $\mathrm{Pb}_{3}(\mathrm{OH})_{2}\left(\mathrm{NH}_{2} \mathrm{SO}_{3}\right)_{4}$ containing divalent $\mathrm{Pb}^{2+}$ cations are synthesized by a hydrothermal synthesis method using $\mathrm{PbO}$ and $\mathrm{NH}_{2} \mathrm{SO}_{3} \mathrm{H}$ as source materials (Wickleder, 2005). The crystal has an orthorhombic structure with space group Pnma, and consists of chains of $\mathrm{OH}^{-}$centered $\left[\mathrm{Pb}^{2+}\right]_{3}$ triangles and four types of $\mathrm{PbO}(\mathrm{N})_{x}(x=8-10)$ polyhedra (Wickleder, 2005). It is noticed that the chemical formula of the $\mathrm{Pb}_{3}(\mathrm{OH})_{2}\left(\mathrm{NH}_{2} \mathrm{SO}_{3}\right)_{4}$ crystal differs from that of the $\mathrm{A}\left(\mathrm{NH}_{2} \mathrm{SO}_{3}\right)_{2}$-type crystal in spite of that lead cation has a positive charge of $+2 e$. Studies of physical and chemical properties of the compounds containing the divalent cation and the sulfamate anion are extremely rare. 
The purpose of this paper is to synthesize the title compound containing $\mathrm{Pb}^{2+}$ and $\mathrm{NSO}_{3}{ }^{3-}$ ions by using a gel method, and to determine the crystal structure at room temperature by X-ray diffraction.

\section{Experimental}

\subsection{Crystal Growth}

Single crystals of $\mathrm{PbHNSO}_{3}$ were grown at room temperature by a slow diffusion method using agar-agar gel with U-shape tubes. The U-tubes with both ends open, arm length of $180 \mathrm{~mm}$ and diameter of $18 \mathrm{~mm}$ were used as crystallizing vessels. The agar-agar gels of concentration $1 \%$ were prepared by dissolving $2.0 \mathrm{~g}$ of agar-agar powder in $200 \mathrm{ml}$ of distilled water at boiling temperature. After setting and aging the agar-agar gel (about $35 \mathrm{ml}$ ) filled up in the U-tubes, $10 \mathrm{ml}$ aqueous solutions of $\mathrm{Pb}\left(\mathrm{NO}_{3}\right)_{2}(0.2$ to $1.5 \mathrm{M})$ and of $\mathrm{NH}_{2} \mathrm{SO}_{3} \mathrm{H}(0.2$ to $2 \mathrm{M})$ were poured into each two limbs of a number of the tubes. The ions from the solutions diffused through the agar-agar gel, and prismatic shaped dark brown crystals with dimensions of typically less than $0.5 \times 0.5 \times 2.0 \mathrm{~mm}$ were grown in the gels of all the tubes over several months.

\subsection{Thermal Measurements (DSC and TG-DTA)}

Differential scanning calorimetry (DSC) and thermogravimetric-differential thermal analysis (TG-DTA) measurements were carried out using DSC7020 and TG/DTA7300 systems from Seiko Instruments Inc, respectively. The amounts of the sample for the DSC and TG-DTA measurements varied between 2.63 and 7.68 $\mathrm{mg}$. The heating rates for the DSC and TG-DTA measurements were 10 and $20 \mathrm{~K} / \mathrm{min}$ with flowing dry $\mathrm{N}_{2}$ gas at 40 and $200 \mathrm{ml} / \mathrm{min}$, respectively.

Table 1. Crystal data, intensity collection and structure refinement for $\mathrm{PbHNSO}_{3}$

\begin{tabular}{|c|c|}
\hline Compound, $M_{r}$ & $\mathrm{PbHNSO}_{3}, 302.27$ \\
\hline Crystal shape, color & Prism, dark brown \\
\hline Temperature & $297 \mathrm{~K}$ \\
\hline Crystal system, space group & Orthorhombic, Pnma \\
\hline Lattice constants & $\begin{array}{l}a=8.4690(6) \AA, b=5.3934(4) \AA \\
c=6.9530(4) \AA\end{array}$ \\
\hline$V, Z$ & $317.59(4) \AA^{3}, 4$ \\
\hline$D($ cal. $), \mu($ Mo $K \alpha), F(000)$ & $6.322 \mathrm{Mg} / \mathrm{m}^{3}, 53.59 \mathrm{~mm}^{-1}, 520$ \\
\hline Sample shape, size in diameter & Sphere, $2 r=0.32 \mathrm{~mm}$ \\
\hline$\theta$ range for data collection & $3.79-38.66^{\circ}$ \\
\hline Index ranges & $-14 \leq h \leq 14,-9 \leq k \leq 9,-12 \leq l \leq 12$ \\
\hline Reflections collected, unique & $6500,955[R($ int $)=0.1191]$ \\
\hline Completeness to $\theta$ & $97.8 \%$ \\
\hline Absorption correction type & Spherical \\
\hline Transmission factor $T_{\min }-T_{\max }$ & $0.0013-0.0157$ \\
\hline Data, parameter & $687[I>2 \sigma(I)], 35$ \\
\hline Final $R$ indices & $R_{1}=0.0418, w R_{2}=0.1243$ \\
\hline$R$ indices (all data) & $R_{1}=0.0586, w R_{2}=0.1285$ \\
\hline Weighting scheme & $\begin{array}{l}w=1 /\left[\sigma^{2}\left(F_{\mathrm{o}}^{2}\right)+(0.0340 P)^{2}\right] \\
P=\left(F_{\mathrm{o}}^{2}+2 F_{\mathrm{c}}^{2}\right) / 3\end{array}$ \\
\hline Goodness-of-fit on $F^{2}$ & 1.239 \\
\hline Extinction coefficient & $0.0(6) \times 10^{-3}$ \\
\hline Largest diff. peak and hole & 5.257 and $-3.308 \mathrm{e} \AA^{-3}$ \\
\hline
\end{tabular}

\subsection{X-Ray Crystal Structure Determination}

The X-ray diffraction measurements were carried out by using a Rigaku Saturn CCD X-ray diffractometer with graphite monochromated Mo $K_{\alpha}$ radiation $(\lambda=0.71073 \AA)$. Diffraction data were collected at $297 \mathrm{~K}$ using an $\omega$ scan mode with a detector distance of $40 \mathrm{~mm}$ to the sample crystal, and processed using the CrystalClear software package. Intensity data were corrected for Lorentz polarization and absorption effects. The structure 
was solved with direct methods of SIR2008 and refined on $F^{2}$ by full-matrix least-squares methods using SHELXL-97 program in the WinGX program package (Burla et al., 2007; Farrugia, 1999; Scheldrick, 1997). A summary of crystal data, intensity collection and structure refinement is given in Table 1. The highest peak and deepest hole of residual electron density in the final difference Fourier map were 5.257 and -3.308 e $\AA^{-3}$, and were located 0.84 and $0.67 \AA$ from the $\mathrm{Pb}$ atom, respectively. The large values of the residual electron density are probably due to an effect associated with the presence of the heavy lead atom and to using wide-angle reflection data in the least-squares refinement.

\section{Results and Discussion}

\subsection{Thermal Analysis}

Figure 1 shows the TG, differential TG (DTG), and DTA thermal analysis curves at temperatures up to $1320 \mathrm{~K}$. Broad and three small endothermic peaks in the DTA curve are observed at about 960, 1150, 1220, and $1240 \mathrm{~K}$, respectively. The broad peak at $960 \mathrm{~K}$ corresponds to the temperature at which steep weight loss occurs in the TG curve and to a first peak in the DTG curve. The weight loss of about $4.6 \%$ is observed at around $960 \mathrm{~K}$. It is also seen that the small exothermic peaks at 1150 and $1240 \mathrm{~K}$ in the DTA curve are nearly equal to start and end temperatures of a second weight loss in the TG curve. The weight loss of about $9.5 \%$ is observed in the temperature range of $1150-1240 \mathrm{~K}$.

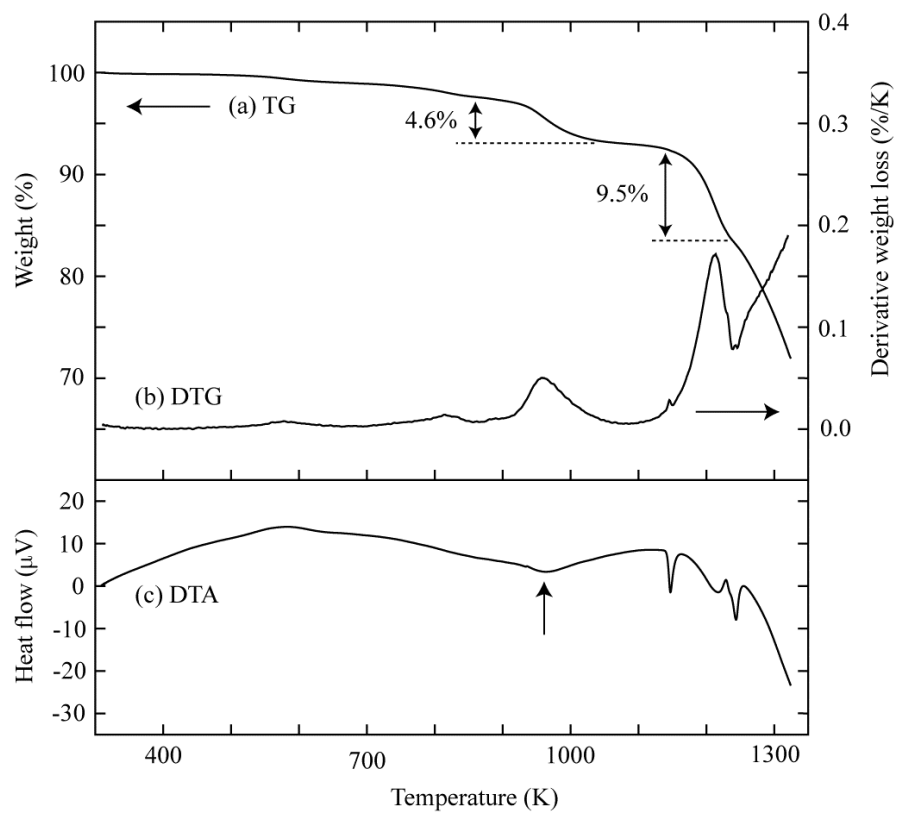

Figure 1. TG, DTG, and DTA thermograms of $\mathrm{PbHNSO}_{3}$ on heating process. Sample weight was $6.031 \mathrm{mg}$, and the heating rate was $20 \mathrm{~K} / \mathrm{min}$ under a dry nitrogen flux of $200 \mathrm{ml} / \mathrm{min}$

The chemical formula of the sample crystal is represented as $\mathrm{PbHNSO}_{3}$ with a molecular weight of 302.27 by the results of crystal structure determination, as described in the subsection on X-ray diffraction below. The theoretical weight loss at around $960 \mathrm{~K}$, assuming the decomposition accompanied by the evolution of $\mathrm{N}_{2}$, is calculated to be $4.63 \%(=14.01 / 302.27 \times 100)$. This value is very close to the experimental weight loss of $4.6 \%$. Moreover, the weight loss in the temperature range of 1150-1240 K, assuming the decomposition accompanied by the evolution of $\mathrm{O}_{2}$ composed by two oxygen atoms, is calculated to be $10.59 \%(=2 \times 16.00 / 302.27 \times 100)$. The obtained value of $10.59 \%$ may also be consistent with the experimental weight loss of $9.5 \%$ in the temperature range of $1150-1240 \mathrm{~K}$. Therefore, it is probably that the weight losses below $1240 \mathrm{~K}$ are caused by the evolutions of $\mathrm{N}_{2}$ and $\mathrm{O}_{2}$ due to the thermal decomposition of $\mathrm{PbHNSO}_{3}$. It is seen that there is a drastic increase in weight loss above $1240 \mathrm{~K}$ in the TG curve. This is presumed to be caused by the evolutions of $\mathrm{SO}$ and $\mathrm{SO}_{2}$ due to the thermal decomposition at high temperatures above $1240 \mathrm{~K}$.

No significant endothermic and exothermic peaks in DSC curves were observed in the temperature range of $100-520 \mathrm{~K}$. Generally, a clear peak in DSC and DTA curves is attributed to the change of exchange energy at phase transition. Therefore, the results of DSC and TG-DTA analysis indicate that there is no phase transition of 
$\mathrm{PbHNSO}_{3}$ in the temperature range of 100-960 K.

\subsection{X-Ray Crystal Structure Description}

The crystal structure of a single crystal grown from the agar-agar gel was analyzed by X-ray diffraction. The observed lattice parameters indicated that it belongs to an orthorhombic system. The systematic extinctions in the observed reflections revealed that the possible space group is $P n 2_{1} a$ or Pnma. Furthermore, the intensity statistics indicated that the space group belongs to centrosymmetric $\mathrm{mmm}$ Laue class. Thus, the space group of the crystal was determined to be Pnma.

The atomic positions of independent $\mathrm{Pb}, \mathrm{N}, \mathrm{S}$, and two $\mathrm{O}$ atoms in the unit cell were found by the direct method from X-ray diffraction data. The $\mathrm{Pb}, \mathrm{N}, \mathrm{S}$ atoms and one of the $\mathrm{O}$ atoms were located at special positions on a crystallographic mirror plane parallel to the $a c$-plane, and the other $\mathrm{O}$ atom was constrained at equivalent positions across the mirror plane. It was confirmed that a minimum $R$-value was obtained when the $\mathrm{N}$ atom was located at the special position determined by the direct method. The positions of remaining hydrogen atoms were not found by difference Fourier syntheses. Thus, the complete chemical formula of the crystal was not determined well in the least-squares refinement. The chemical formula built up by using the $\mathrm{Pb}, \mathrm{N}, \mathrm{S}$, and $\mathrm{O}$ atoms with an electrical charge of ions was indicated by $\mathrm{Pb}^{2+} \mathrm{NSO}_{3}{ }^{3-}$. It was found from the formula that there is one excess electron giving the negative charge of $-1 e$. Therefore, it was necessary to add a hydrogen atom to the formula in order to suppress the electron concentration by one positive charge. The chemical formula of the crystal was considered to be represented as $\mathrm{PbHNSO}_{3}$.

Table 2. Atomic coordinates and thermal parameters at $297 \mathrm{~K}$ with standard deviations in brackets. The anisotropic thermal parameters $\left(\times 10^{4} \AA^{2}\right)$ are defined as $\exp \left[-2 \pi^{2}\left(U_{11} a^{* 2} h^{2}+U_{22} b^{* 2} k^{2}+U_{33} c^{* 2} l^{2}+2 U_{23} b^{*} c^{*} k l\right.\right.$ $\left.\left.+2 U_{13} a^{*} c^{*} h l+2 U_{12} a^{*} b^{*} h k\right)\right]$

\begin{tabular}{cccccccccc}
\hline Atom & $x$ & $y$ & $z$ & $U_{11}$ & $U_{22}$ & $U_{33}$ & $U_{23}$ & $U_{13}$ & $U_{12}$ \\
\hline $\mathrm{Pb}$ & $0.31202(6)$ & 0.25 & $0.33279(8)$ & $147(2)$ & $286(3)$ & $199(2)$ & 0 & $12(2)$ & 0 \\
$\mathrm{~N}$ & $0.3077(12)$ & 0.25 & $0.9578(13)$ & $89(37)$ & $154(42)$ & $83(33)$ & 0 & $50(29)$ & 0 \\
$\mathrm{~S}$ & $0.4355(4)$ & 0.25 & $0.8152(4)$ & $93(10)$ & $127(11)$ & $104(10)$ & 0 & $2(9)$ & 0 \\
$\mathrm{O}(1)$ & $0.5908(12)$ & 0.25 & $0.9046(16)$ & $126(44)$ & $308(57)$ & $214(45)$ & 0 & $-62(34)$ & 0 \\
$\mathrm{O}(2)$ & $0.4165(9)$ & $0.0271(14)$ & $0.6914(10)$ & $170(31)$ & $144(27)$ & $207(31)$ & $-41(22)$ & $28(24)$ & $-11(24)$ \\
\hline
\end{tabular}

Table 3. Selected interatomic distances (in $\AA$ ) and angles (in degrees) for $\mathrm{PbHNSO}_{3}$

\begin{tabular}{llllllll}
\hline \multicolumn{3}{c}{ Distances $(\AA)$} \\
\hline $\mathrm{Pb}-\mathrm{N}^{(\mathrm{a})}$ & $2.607(9)$ & $\mathrm{Pb}-\mathrm{N}^{(\mathrm{b})}(2 \mathrm{x})$ & $3.009(5)$ & $\mathrm{N}^{(\mathrm{a})}-\mathrm{Pb}-\mathrm{O}(1)^{(\mathrm{c})}$ & $133.5(3)$ & $\mathrm{N}^{(\mathrm{a})}-\mathrm{Pb}-\mathrm{O}(2)^{(\mathrm{b})}$ & $67.5(2)$ \\
$\mathrm{Pb}-\mathrm{O}(1)^{(\mathrm{c})}$ & $2.616(10)$ & $\mathrm{Pb}-\mathrm{O}(1)^{(\mathrm{d})}(2 \mathrm{x})$ & $3.267(7)$ & $\mathrm{O}(1)^{(\mathrm{c})}-\mathrm{Pb}-\mathrm{O}(2)^{(\mathrm{b})}$ & $74.6(3)$ & $\mathrm{O}(2)^{(\mathrm{b})}-\mathrm{Pb}-\mathrm{O}(2)^{(\mathrm{g})}$ & $69.1(3)$ \\
$\mathrm{Pb}-\mathrm{O}(2)^{(\mathrm{b})}(2 \mathrm{x})$ & $2.635(7)$ & $\mathrm{Pb}-\mathrm{O}(2)^{(\mathrm{e})}(2 \mathrm{x})$ & $2.748(8)$ & $\mathrm{N}^{(\mathrm{a})}-\mathrm{Pb}-\mathrm{O}(2)^{(\mathrm{e})}$ & $87.2(2)$ & $\mathrm{O}(1)^{(\mathrm{c})}-\mathrm{Pb}-\mathrm{O}(2)^{(\mathrm{e})}$ & $130.0(2)$ \\
$\mathrm{Pb}-\mathrm{O}(2)(2 \mathrm{x})$ & $2.906(8)$ & $\mathrm{S}-\mathrm{N}$ & $1.468(10)$ & $\mathrm{O}(2)^{(\mathrm{b})}-\mathrm{Pb}-\mathrm{O}(2)^{(\mathrm{e})}$ & $154.18(8)$ & $\mathrm{O}(2)^{(\mathrm{b})}-\mathrm{Pb}-\mathrm{O}(2)^{(\mathrm{d})}$ & $106.4(2)$ \\
$\mathrm{S}-\mathrm{O}(1)$ & $1.455(11)$ & $\mathrm{S}-\mathrm{O}(2)$ & $1.487(7)$ & $\mathrm{O}(2)^{(\mathrm{e})}-\mathrm{Pb}-\mathrm{O}(2)^{(\mathrm{d})}$ & $65.9(3)$ & $\mathrm{O}(1)-\mathrm{S}-\mathrm{O}(2)$ & $110.2(4)$ \\
$\mathrm{N}-\mathrm{O}(1)$ & $2.426(14)$ & $\mathrm{N}-\mathrm{O}(2)$ & $2.393(10)$ & $\mathrm{O}(1)-\mathrm{S}-\mathrm{N}$ & $112.2(6)$ & $\mathrm{O}(2)-\mathrm{S}-\mathrm{N}$ & $108.1(4)$ \\
$\mathrm{O}(1)-\mathrm{O}(2)$ & $2.413(12)$ & $\mathrm{O}(2)-\mathrm{O}(2)^{(\mathrm{f})}$ & $2.404(15)$ & $\mathrm{O}(2)-\mathrm{S}-\mathrm{O}(2)^{(\mathrm{f})}$ & $107.9(6)$ & & \\
\hline
\end{tabular}

Symmetry codes: (a) $x, y, z-1$; (b) $-x+1 / 2,-y, z-1 / 2$; (c) $x-1 / 2, y,-z+3 / 2$; (d) $-x+1,-y,-z+1$; (e) $-x+1, y+1 / 2,-z+1$; (f) $x,-y+1 / 2, z ;(\mathrm{g})-x+1 / 2, y+1 / 2, z-1 / 2$.

The positional parameters in fractions of the unit cell and the thermal parameters are listed in Table 2. The selected bond lengths $(\AA)$ and angles (degrees) are given in Table 3. Figure 2 shows perspective views of the obtained crystal structure on the $a b$ - and $a c$-planes at room temperature. The observed structure of $\mathrm{PbHNSO}_{3}$ consists of $\mathrm{NSO}_{3}$ pseudo-tetrahedra, $\mathrm{PbO}_{9} \mathrm{~N}_{3}$ polyhedra, and $\mathrm{NSO}_{3}-\mathrm{Pb}-\mathrm{NSO}_{3}$ frameworks. The lengths of three $\mathrm{Pb}-\mathrm{N}$ and nine $\mathrm{Pb}-\mathrm{O}$ bonds in the $\mathrm{PbO}_{9} \mathrm{~N}_{3}$ polyhedron are in the ranges of 2.607(9)-3.009(5) and 2.616(10)-3.267(7) $\AA$, respectively. The $\mathrm{NSO}_{3}-\mathrm{Pb}_{-}-\mathrm{NSO}_{3}$ frameworks are constructed by two neighboring $\mathrm{NSO}_{3}$ pseudo-tetrahedra. The $\mathrm{Pb}$ atom lies roughly midway between the two pseudo-tetrahedra, and is bonded with 
shorter $\mathrm{Pb}-\mathrm{N}(2.607(9) \AA)$ and $\mathrm{Pb}-\mathrm{O}(2.616(10) \AA$ ) bonds, as shown in Figure 2. The bond length of the $\mathrm{Pb}-\mathrm{N}$ bond is slightly shorter than that of the $\mathrm{Pb}-\mathrm{O}$ bonds.

The lengths of one S-N and two S-O bonds in the $\mathrm{NSO}_{3}$ pseudo-tetrahedron of $\mathrm{PbHNSO}_{3}$ are observed to be $1.468(10), 1.455(11)$ and 1.487(7) $\AA$, respectively. No significant difference in the bond length between the S-N and $\mathrm{S}-\mathrm{O}$ bonds is detected. This indicates that there is no significant difference in a quality property between these bonds. On the other hand, there is an obvious difference in the correlation between the S-N and S-O bonds in the $\mathrm{ANH}_{2} \mathrm{SO}_{3}$-type and $\mathrm{Pb}_{3}(\mathrm{OH})_{2}\left(\mathrm{NH}_{2} \mathrm{SO}_{3}\right)_{4}$ crystals (Belaj et al., 1987; Cox et al., 1967; Fukami et al., 2011; Manickkavachagam \& Rajaram, 1984; Wadhawan \& Padmanabhan, 1972; Wickleder, 2005). The length of the S-N bond in $\left[\mathrm{NH}_{2} \mathrm{SO}_{3}\right]^{-}$anions of these crystals is significantly longer than that of the S-O bond. For example, the lengths of the S-N and two S-O bonds in $\mathrm{KNH}_{2} \mathrm{SO}_{3}$ are 1.666(6), 1.459(7) and 1.454(4) $\AA$, respectively (Cox et al., 1967). The $\mathrm{S}-\mathrm{N}$ and $\mathrm{S}-\mathrm{O}$ bond lengths in $\mathrm{Pb}_{3}(\mathrm{OH})_{2}\left(\mathrm{NH}_{2} \mathrm{SO}_{3}\right)_{4}$ fall in the ranges of 1.614(13)-1.662(12) and 1.434(10)-1.482(9) A, respectively (Wickleder, 2005). The difference in the bond length between the S-N and $\mathrm{S}-\mathrm{O}$ bonds has been reported to be related to the difference in the properties of single and double bonds (Cox et al., 1967; Wadhawan \& Padmanabhan, 1972). Thus, it is considered from the results obtained in this study that the S-N bond in $\mathrm{PbHNSO}_{3}$ is substantially a double bond as similar to the S-O bond, and $\mathrm{H}$ atoms are not attached to the $\mathrm{N}$ atom. Because if two $\mathrm{H}$ atoms are bonded to the $\mathrm{N}$ atom, the $\mathrm{S}-\mathrm{N}$ bond would be characterized by the single bond and have longer bond length, which is similar to that in the $\mathrm{ANH}_{2} \mathrm{SO}_{3}$-type and $\mathrm{Pb}_{3}(\mathrm{OH})_{2}\left(\mathrm{NH}_{2} \mathrm{SO}_{3}\right)_{4}$ crystals.

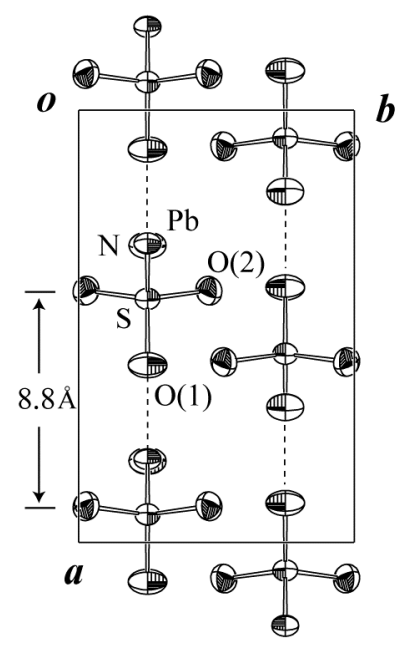

(a)

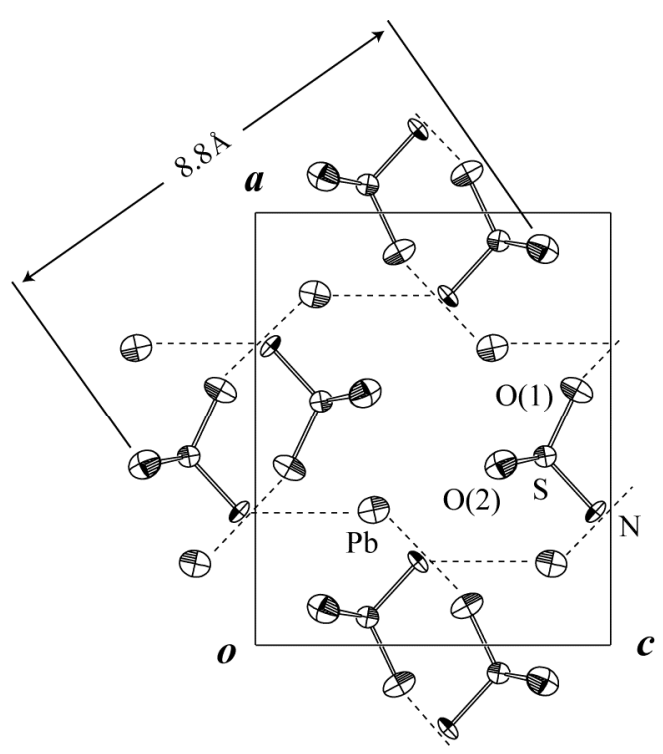

(b)

Figure 2. Projection views of $\mathrm{PbHNSO}_{3}$ crystal structure on the (a) $a b$ - and (b) $a c$-planes at $297 \mathrm{~K}$ with $80 \%$ probability-displacement thermal ellipsoids. The dashed lines show the $\mathrm{Pb}-\mathrm{N}(2.607(9) \AA)$ and $\mathrm{Pb}-\mathrm{O}(1)$

(2.616(10) $\AA$ ) bonds in $\mathrm{NSO}_{3}-\mathrm{Pb}-\mathrm{NSO}_{3}$ frameworks

Fortunately, we realized that the structure of $\mathrm{PbHNSO}_{3}$ is very close to that of $\mathrm{PbSO}_{4}$ (Antao, 2012; Jacobsen et al., 1998). The crystal form of $\mathrm{PbSO}_{4}$ belongs to the same orthorhombic Pnma space group, and moreover, the cell parameters, the positional parameters of all atoms, and the bond lengths are very similar to those of $\mathrm{PbHNSO}_{3}$. Even though there are differences in the chemical formula and crystal color. One of the two $\mathrm{O}$ atoms located on the mirror plane in $\mathrm{PbSO}_{4}$ is corresponding to the $\mathrm{N}$ atom in $\mathrm{PbHNSO}_{3}$, and the $\mathrm{PbSO}_{4}$ crystal is colorless and transparent (Antao, 2012; Jacobsen et al., 1998; Kaminskii et al., 2011). It is probably that the origin of such similar structures is due to the relatively small difference in X-ray atomic scattering factors between $\mathrm{N}$ and $\mathrm{O}$ atoms.

\subsection{Crystal Color}

The color of the $\mathrm{PbHNSO}_{3}$ crystal grown by the gel method is dark brown. In general, it is well known that an unique brown color of materials is produced by the absorption of blue wavelengths of light. Thus, it is necessary for clarification of the crystal color to consider the excitation of electrons in the crystal. The energy levels $E_{n}$ of 
an electron in a simple potential well express as the formula, $E_{n}=h^{2} n^{2} /\left(8 m_{\mathrm{e}} L^{2}\right)$, where $h$ is Planck's constant, $n$ is a principal quantum number, $m_{\mathrm{e}}$ is the rest mass of electron, and $L$ is the width of the potential well. The $\mathrm{Pb}$ atom is bonded to the two $\mathrm{NSO}_{3}$ pseudo-tetrahedra, and the $\mathrm{NSO}_{3}-\mathrm{Pb}-\mathrm{NSO}_{3}$ frameworks are constructed in the crystal, as shown in Figure 2. It is seen that the two $\mathrm{NSO}_{3}$ pseudo-tetrahedra and the $\mathrm{Pb}$ atom in the frameworks are arranged nearly in a straight line. The distances of $\mathrm{N}-\mathrm{O}(1), \mathrm{N}-\mathrm{O}(2), \mathrm{O}(1)-\mathrm{O}(2)$, and two $\mathrm{O}(2)-\mathrm{O}(2)$ on the edges of the $\mathrm{NSO}_{3}-\mathrm{Pb}-\mathrm{NSO}_{3}$ framework are 7.977(14), 7.939(12), 8.577(13), 8.847(10), and 9.168(10) $\AA$, respectively. The widths of the potential well produced by the $\mathrm{NSO}_{3}-\mathrm{Pb}-\mathrm{NSO}_{3}$ framework are considered to correspond to these distances. Therefore, the energies $\Delta E\left(=E_{3}-E_{2}\right)$ of the excess electrons from the ground $(n=2)$ state to the first $(n=3)$ excited state of the $\mathrm{N}$ and $\mathrm{O}$ atoms are calculated using the above formula with these distances. The absorption wavelengths $\lambda(=h c / \Delta E)$ in the crystal by the excitation of the electrons are calculated to be in the range of $420-550 \mathrm{~nm}$. This range is very close to the wavelength range $(430-500 \mathrm{~nm})$ of blue and blue-green lights. Thus, it is concluded that the dark brown color of $\mathrm{PbHNSO}_{3}$ is produced by the absorption of the wavelengths in the range of $420-550 \mathrm{~nm}$ in the crystal which is due to the excitation of the excess electrons.

Since the crystal structure of $\mathrm{PbSO}_{4}$ is very close to that of $\mathrm{PbHNSO}_{3}$, there are $\mathrm{SO}_{4}-\mathrm{Pb}_{-} \mathrm{SO}_{4}$ frameworks of a nearly straight line in the $\mathrm{PbSO}_{4}$ crystal (Antao, 2012; Jacobsen et al., 1998). The $\mathrm{Pb}$ atom is bonded to the two neighboring $\mathrm{SO}_{4}$ tetrahedra, and the two $\mathrm{Pb}-\mathrm{O}$ distances are 2.609(7) and 2.610(6) $\AA$. Moreover, the O-O distances on the edges of the $\mathrm{SO}_{4}-\mathrm{Pb}_{-} \mathrm{SO}_{4}$ framework are in the range of 7.960(8)-9.175(6) $\AA$. This range of the distance is very similar to that of $\mathrm{PbHNSO}_{3}$. Based on the above formulas and these distances, the absorption wavelengths in the crystal are calculated to be in the range of 420-560 nm. However, the $\mathrm{PbSO}_{4}$ crystal is colorless and transparent, and does not show a dark brown color (Kaminskii et al., 2011). Thus, it is considered from these results that no excess electrons for the excitation exist in the $\mathrm{PbSO}_{4}$ crystal, and the origin of the crystal color is caused by the presence or absence of $\mathrm{N}$ atoms in the crystals. The colorless and transparent characters of $\mathrm{PbSO}_{4}$ would be produced by the absence of the $\mathrm{N}$ atom in the crystal, and the excess electrons in the $\mathrm{PbHNSO}_{3}$ crystal would be stripped from the $\mathrm{N}$ atoms.

\section{Conclusion}

We have studied the synthesis, structural features, and physical properties of $\mathrm{PbHNSO}_{3}$. A new type of the $\mathrm{PbHNSO}_{3}$ crystal, which is dark brown in color, is grown from the agar-agar gel by the gel method with slow diffusion. From the results of DSC and TG-DTA analyses, it is found that there is no structural phase transition of $\mathrm{PbHNSO}_{3}$ in the temperature range of 100-1320 K, and the thermal decomposition starts at about $960 \mathrm{~K}$. The crystal structure is determined to be orthorhombic with space group Pnma by means of single-crystal X-ray diffraction at room temperature. It is found that the structure consists of the $\mathrm{NSO}_{3}$ pseudo-tetrahedra, the $\mathrm{PbO}_{9} \mathrm{~N}_{3}$ polyhedra, and the $\mathrm{NSO}_{3}-\mathrm{Pb}-\mathrm{NSO}_{3}$ frameworks, and is very close to that of $\mathrm{PbSO}_{4}$. The excess electrons in the simple potential wells produced by the $\mathrm{NSO}_{3}-\mathrm{Pb}-\mathrm{NSO}_{3}$ framework are possible to be stripped from the $\mathrm{N}$ atoms. The dark brown color of $\mathrm{PbHNSO}_{3}$ is suggested to be caused by the absorption of blue wavelengths of light due to the excitation of the electrons in the potential wells.

\section{References}

Angerer, P., Tillmanns, E., \& Wildner, M. (1999). Crystal structure investigations of amide sulfate tetrahydrates with divalent cations. Croatica Chemica Acta, 72(2-3), 295-310. Retrieved from http://public.carnet.hr/ccacaa/CCA-PDF/cca1999/v72-n2_n3/CCA_72_1999_295-310_ANGERER.pdf

Antao, S. M. (2012). Structural trends for celestite $\left(\mathrm{SrSO}_{4}\right)$, anglesite $\left(\mathrm{PbSO}_{4}\right)$, and barite $\left(\mathrm{BaSO}_{4}\right)$ : Confirmation of expected variations within the $\mathrm{SO}_{4}$. American Mineralogist, 97(4), 661-665. http://dx.doi.org/10.2138/am.2012.3905

Belaj, F., Kratky, C., Nachbaur, E., \& Popitsch, A. (1987). Kristallstruktur von monosilber(I)amidosulfat, $\mathrm{AgSO}_{3} \mathrm{NH}_{2}$. Monatsh. Chem., 118(1), 19-23. http://dx.doi.org/10.1007/BF00810036

Benson, G. A, \& Spillane, W. J. (1980). Sulfamic acid and its N-substituted derivatives. Chem. Rev., 80(2), 151-186. http://dx.doi.org/10.1021/cr60324a002

Budurov, S., Tzolova, G., \& Bohatý, L. (1997). New structural phase transitions in potassium and sodium amidosulfonates. Thermochimica Acta, 307(1), 91-96. http://dx.doi.org/10.1016/S0040-6031(97)00360-2

Burla, M. C., Caliandro, R., Camalli, M., Carrozzini, B., Cascarano, G. L., Caro, L. D., ... Spagna, R. (2007). IL MILIONE: A suite of computer programs for crystal structure solution of proteins. J. Appl. Crystallogr., 40(3), 609-613. http://dx.doi.org/10.1107/S0021889807010941

Cox, G. W., Sabine, T. M., Padmanabhan, V. M., Ban, N. T., Chung, M. K., \& Surjadi, A. J. (1967). A neutron diffraction study of potassium sulphamate, $\mathrm{KSO}_{3} \mathrm{NH}_{2}$. Acta Crystallogr., 23(4), 578-581. 
http://dx.doi.org/10.1107/S0365110X67003238

Farrugia, L. J. (1999). WinGX suite for small-molecule single-crystal crystallography. J. Appl. Crystallogr., 32(4), 837-838. http://dx.doi.org/10.1107/S0021889899006020

Fukami, T., Kyan, T., Nakano, K., \& Chen, R. H. (2011). Crystal structure and phase transition of single crystalline $\mathrm{CsNH}_{2} \mathrm{SO}_{3}$. Cryst. Res. Technol., 46(3), 287-291. http://dx.doi.org/10.1002/crat.201000623

Haussühl, H., \& Haussühl, S. (1995). Elastic properties of sulfamic acid and sulfamates of Li, Na, K, Rb, Cs, Tl, $\mathrm{NH}_{4}, \quad \mathrm{C}\left(\mathrm{NH}_{2}\right)_{3}$ and $\left(\mathrm{CH}_{3}\right)_{3} \mathrm{NCH}_{2} \mathrm{COOH} . \quad Z$. Kristallogr., 210(4), 269-275. http://dx.doi.org/10.1524/zkri.1995.210.4.269

Jacobsen, S. D., Smyth, J. R., Swope, R. J., \& Downs, R. T. (1998). Rigid-body character of the $\mathrm{SO}_{4}$ groups in celestine, anglesite and barite. Can. Mineral., 36(4), 1053-1060. Retrieved from http://www.canmin.org/content/36/4/1053.full.pdf

Kaminskii, A. A., Bohatý, L., Becker, P., Rhee, H., Eichler, H. J., Lux, O., \& Koltashev, V. V. (2011). Stimulated raman scattering in natural crystals of $\mathrm{SrSO}_{4}, \mathrm{BaSO}_{4}$ and $\mathrm{PbSO}_{4}$ : High-order stokes and anti-stokes generation with single-wavelength UV, visible, and near-IR excitation, as well as cascaded up-conversion nonlinear $\chi^{(3)} \leftrightarrow \chi^{(3)}$ lasing effects under dual-wavelength picosecond collinear coherent pumping. Appl. Phys. B, 105(2), 363-378. http://dx.doi.org/10.1007/s00340-011-4388-4

Kumar, A. S., Iype, L., Rajesh, R., Varughese, G., Joseph, G., \& Louis, G. (2011). Electrical conductivity and dielectric properties of potassium sulfamate single crystals. Cryst. Res. Technol., 46(10), 1027-1034. http://dx.doi.org/10.1002/crat.201000135

Manickkavachagam, R., \& Rajaram, R. K. (1984). Crystal structure of anhydrous sodium sulphamate. Z. Kristallogr., 168(1-4), 179-185. http://dx.doi.org/10.1524/zkri.1984.168.1-4.179

Scheldrick, G. M. (1997). SHELXL-97, Program for crystal structure refinement (University of Göttingen, Germany). Retrieved from http://shelx.uni-ac.gwdg.de/SHELX/

Varughese, G., Kumar, A. S., \& Louis, G. (2010). Detection of elastic and electric conductivity anomalies in potassium sulphamate single crystal. Physica B, 405(7), 1813-1816. http://dx.doi.org/10.1016/j.physb.2010.01.052

Wadhawan, V. K., \& Padmanabhan, V. M. (1972). The crystal structure of ammonium sulphamate. Acta Crystallogr. B, 28(6), 1903-1907. http://dx.doi.org/10.1107/S0567740872005205

Wickleder, M. S. (2005). Chains of $\mathrm{OH}^{-}$-centered $\left[\mathrm{Pb}^{2+}\right]_{3}$ triangles in the crystal structure of $\mathrm{Pb}_{3}(\mathrm{OH})_{2}\left(\mathrm{NH}_{2} \mathrm{SO}_{3}\right)_{4}$. Z. Anorg. Allg. Chem., 631(13-14), 2540-2543. http://dx.doi.org/10.1002/zaac.200500176 